\title{
ENHANCING STUDENTS' SPEAKING SKILL USING COMMUNICATIVE LANGUAGE TEACHING METHOD
}

\author{
Jeisica Lumy
}

\begin{abstract}
This study investigated the effect of the implementation of communicative language teaching method in enhancing speaking Skill of the third semester students at English Department of Manado State University. This was a quantitative study using true experimental group and pre-posttest design. The sample was one class from third semester who enrolled in speaking subject. The data obtained was computed through $t$-test to see the significant difference occurred between the control and experimental group. From the calculation, $t$-test value is 2.932 based on the distribution of $t$-table $\alpha$ 0,05 with degrees of freedom $n_{1}+n_{2}-2=12+12-2=22$ and tabulated $t$-test value 2.074. from the calculation, it is clearly seen that $t$-test value is bigger than tabulated $t$-test value. $t$-test value $=2.932$ $\gg t$-tabulated $=2.074$. seen from the final result after computing the mean score of both groups, the experimental group who were taught according to communicative language teaching principles achieved higher score (23.75) than the control group who weren't taught according to communicative language teaching principles (12.08). According to the result, the use of Communicative Language Teaching method is effective in enhancing students' speaking skill.
\end{abstract}

Keywords: Students' Speaking skill; Communicative Language Teaching Method.

\section{INTRODUCTION}

English is the world's lingua franca, by which people around the world use to communicate with other. It's a world wide's most used language in many fields of social-life and used in many areas such as education, technology, science and so many more. A lingua franca, however, As stated by Gordin (2015), is a "world language- one spoken internationally by a large number of people - is a language that may function as a global lingua franca" In understanding, English is the international language people use to communicate with those who don't share the same native language, particularly if English become their third language. English has become something indispensable in this era. It is vitally necessary for good understanding in communication regarding many countries around the world have adopted several English words to be put as if they are the non-native English speaking countries' native language. 
people nowadays have used English a lot more than they use their countries' native language, say that it is what happens in today's world although some of them are grammatically wrong but semantically accepted and understandable.

The need of English has also grown in non-native English speaking country like Indonesia. Many foreigners come to Indonesia for either travelling, business, or merely just pay a visit. Therefore, the demand for Indonesian to be able to communicate in English has also increased drastically.

The writer has been very concerned due to the numbers of erroneous English utterances that people in non-native English speaking country make and puts interest regarding the needs of English proficiency in where she is teaching. Many students in her department asked to do them favors as to help them manage their English usage, particularly in speaking skill. Students asked about how to be good in using English and what method that requires to be so in a way more communicative than the other.

The study to be reported was conducted is in English department of Manado state university, concerning the $3^{\text {rd }}$ semester students. the main goal of English department is to produce a high qualified students who are capable of using English in their daily life and in their career (since one of the pre-requisites for many field of job careers suggest that a candidate has to be good in English). Then, the department itself is required to provide human resources that are able to use English. It is also one of the writer's responsibilities to work with these students in achieving the main goal of English department and producing good English speaking is inevitably inarguable.

However, as the writer has experienced throughout her teaching activity towards the $3^{\text {rd }}$ semester earlier this semester, the students are lack in speaking skill. The writer had assigned them a kind of test to see how far their skill in using English, the writer had first assigned a topic to be talked about by an individual and also a dialog in which students had to respond to and stimulate their speaking skill. The results were not as expected out of $3^{\text {rd }}$ semester students who have had their speaking subject through $1^{\text {st }}$ and $2^{\text {nd }}$ semester. They had difficulties in their daily use of English, such as describing a place or even listen to a simple vocabulary that is said by someone. For students at their level, they are supposed to be categorized as intermediate but as a matter of fact they are more of beginners. The writer assumes based on the result that these students have a low skill especially in speaking and listening. Therefore, the writer interested in conducting a research in which students will be taught according to a different method that they used to be taught with. A method which makes lessons more communicative or interactive

Teaching method that are most likely to be applied in English teaching, however, emphasizes on mastering vocabulary and working on their retention. Teachers happen to 
stand for hours and make themselves the center of the whole learning activity, hoping that students will absorb what is said by teachers without giving them chance to either show what they are capable of or give feed back to what teachers are saying, particularly, teachers are often forget to stimulate students understanding by letting them sit and just listen. Usually at the end of a task, teachers will only give them chance to ask questions.

The explanation above is what we call teacher centered learning, where teachers become the center of a learning activity and somehow makes the process become one way communication. Seemingly, teachers will only give drills and practices. That way, students will not be stimulated enough because the focus is only on forms language along with its structures and limited only on what the teachers know about the language.

Students nowadays need a method that stimulates their knowledge and usage of English. Thus, students centered learning has to be required in every learning activity. Students centered learning shifts the focus of instructor, where the teachers' role is only as facilitator. Stand at the opposite of TCL, SCL puts learners' interest first, acknowledge that learners' voice is the center of the whole learning experience. In this learning system, teachers take the role of students, where, they do what students normally do; being passive. SCL requires students to be independent and active.

As to the case rises above, the writer chooses Communicative Language Teaching method to fulfill the need of students. Alongside the background of study above raises the following question to be solved in this research; will the students of English department who are taught speaking using communicative language teaching method get higher score than those who are not?

The purpose of this study is to examine whether or not the students who are taught speaking using CLT get higher score than those who are not.This study was delimited only to some speaking material, those are in dialog, expressing anger and disappointment and describing people or places. The sample was delimited only in Speaking class of the third semester.

\section{REVIEW OF LITERATURE}

\section{Communicative Language Teaching}

Communicative Language Teaching underlines that students need to perform a language more often, generates an unrehearsed performance of language without teachers interference in correcting the grammatical error. Brown (1994) points out that classroom goals are focused upon in all the components of communication competence; they are not restricted to grammatical or linguistic competence (As cited in Coskun, A. 2011). 
There are many researchers have presented their understandings about Communicative language teaching, Ying (2010) states that CLT is an approach to the teaching of second languages that emphasizes interaction as both the means and the ultimate goal of learning a language. It is also referred to as a "communicative approach to the teaching of foreign languages" or simply as the "communicative approach". Related to the quoted statement, Larsen-Freeman (2000) states that CLT aims broadly at the theoretical perspective of a communicative approach by enabling communication. Communicative competence is the goal of language teaching by acknowledging the interdependence of language and communication. It is clear that CLT here means that teachers use communication as the main teaching approach in improving students' communicative competence (Larsen-freeman 2000).

In order to gain students communicative competence, any practice that allows students to stimulate their speaking skill must be widely accepted, thus, teachers and students shift roles. Paulista and Gomez stated that the role of teachers and learners in the classroom was changed as result of the CLT approach introduction. Instruction has become learner-centered rather than teacher-centered. Hence, the teacher assumes two main roles both facilitator and monitor of the learning process (Paulista \& Gomez, 2014).

CLT engages students centered learning as the main method to master English proficiency, where students make interactions with another students as teachers monitoring the activity conducted during the learning experience, as stated by Paulista\&Gomez "on the other hand, the role of learner is defined as negotiator. Thus, the students are expected to interact with their classmates instead of interacting with the teacher because it is a learnercentered approach. So, students participate in classroom activities which entail cooperative rather than individualistic learning and they are also responsible or the process of learning a language" (Paulista \& Gomez, 2014). A complementary statement also puts out by beale 2002 ( as cited in khan, 2013) that is "Communicative Language Teaching is said to be one of the latest pedagogic approach which is based on the principles of motivation enforced learning. CLT incorporates the idea of interaction considering it as an essential element of the whole process and output. The basic pedagogical principle of CLT is that successful acquisition of the target language on the part of the learners depends on the amount of interaction and negotiation of meaning that they participate in. in this way, the integration of language input and output contributes to the language development system of the learners (Baele, 2002 as cited in Khan, 2013)

Richards (2006) summarizes the following principles of CLT:

1. 'Authentic language' in real context should be introduced in the classroom whenever possible. It is the language used for day-today communication or functional purpose. 
2. By teaching language, learner should be able to make out speaker's or writer's intention. So that they will be communicatively competent.

3. There should be connectivity among all the language skills such as listening, speaking, reading and writing together since they are regularly used in real life.

4. The target language is a vehicle for classroom communication, not just the object of study. Hence, attention should be given to teaching language for communication.

5. One function may have different linguistic forms. As the language is taught for the functional purpose, a variety of linguistic forms are presented together.

6. Students have to learn language properties i.e. cohesion and coherence which are helpful to combine sentences together. It is essential for them as they work with language at the discourse or super sentential (above sentence) level.

7. In CLT, games, role plays, group work, pair work, etc. play an important role as they have certain feature in common to learn language effectively.

8. Errors are tolerated and treated as a natural outcome of the development of communication skills.

9. Proper situations should be created by the teacher so as to promote communication in the classroom.

10. The social contexts of the communicative situations are essential for giving meaning to the utterances.

11. The grammar and vocabulary that the students learn follow from the functions, situational context and the role of the interlocutors.

\section{SPEAKING SKILL}

\section{Speaking is one's ability to extract thoughts and feelings through words.}

Speaking is one of the most crucial competencies in learning a language. One should be able to master speaking skill in order to acquire good communication. According to Boonkit (2010) "Speaking is one of the four macro skills to be developed as a means of effective communication in both first and second language learning context."

For English as Foreign Language (EFL) learners, the importance of speaking skill mastery stands alongside the importance of developing vocabularies in daily usage. We communicate with people around us to state and/or express our thoughts, feelings, ideas and also to know others ideas as we exchange information with one another through spoken language. EFL learners in Indonesia are also taught ways to develop speaking skill, as it is referred in competency based curriculum (Kurikulum berbasis kompetensi or KBK) in 2004, the standard competency of English for senior high school is formulated to be able to communicate in oral and written English fluently and accurately in discussions and 
monologues in the form of narrative, procedure, spoof, recount, news item, descriptive, anecdote, exposition, discussion, commentary, and review (DEPDIKNAS 2003, in Munawar 2015.

Speaking is once again a crucial part of skills that EFL learners should master. In speaking, there are types that are classified under the umbrella of speaking skill. According to Vilagran (2008), there are three types of speaking, those are interactive speaking s, partially interactive speaking and non-interactive speaking. Vilagran then clarifies each type of those: Interactive Speaking: face-to-face interaction, telephone calls, we are alternately listening and speaking, chance to ask for clarification, repetition, or solver speech from our conversation partner. Partially Interactive speaking: giving a speech to live audience where the convention is that the audience does not speak, the speaker checks comprehension from the audience's faces. Non-Interactive speaking: when recording a speech for a radio broadcast, performing a play, reciting a poem, singing. (Vilagran 2008).

Before teachers try to enhance their students speaking ability, they must first understand that people have their own challenges in their speaking activity. As the writer had experienced, she has encountered types of speakers, for instance, an utterance from a person comes naturally. When a student tries to stimulate their speaking skill, it happens to be uttered as if grammatical rule doesn't apply to them. The writer then comprehends that it is not that they have no idea about grammar or the structures, it is only that they learn to adjust themselves to speak appropriately. As long as what comes out of their mouth is appropriate and it conveys the thoughts they have, then it is acceptable. There will still be speaking interaction between speaker and hearer. Dendrinos (P.4, P.5) states "What is involved in producing a conversational utterance?" that apart from being grammatical, the utterance must also be appropriate on many levels at the same time; it must conform the speaker's aim, to the role relationships between interactants, to the setting, topic, linguistic context, etc."

From the explanation above, we may conclude that interaction is the aim of speaking experience. Richards (2008) stated that the interaction conducted in a talk refers to what we normally mean by 'conversation' and describes interaction that serves a primarily social function. When people meet, they exchange greetings, engage in small talk, recount recent experiences. We normally do so in a means of creating comfortable situation to connect with others in interaction.

Richards also puts out the main features of talk as interaction, those are:

- Has a primarily social function

- Reflects role relationships

- Reflects speaker's identity

- May be formal or casual 
- Uses conversational conventions

- Reflect degree of politeness

- Employs many generic words

- Uses conversational register

- Is jointly constructed

(Richards, J. 2008)

\section{FACTORS AFFECTING SPEAKING SKILL DEVELOPMENT}

Before going further on applying communicative methods to help students with their speaking skill, teachers must note that there are inevitable problems students may encounter before, during and after taking speaking skill class. According to Tuan\&Mai, 2015.(cited In Leong\&Ahmadi 2017.), if teachers want to help learners overcome their difficulties in learning speaking skill, they should identify some actors that influence their speaking performance. Learners' speaking performance are influenced by factors like performance conditions. Performance conditions, affective factors, listening skill, and feedback during speaking tasks (Tuan \& Mai, 2015)

Generally, English as Foreign Language (EFL) learners have troubles in conveying their thoughts even after constructing sentences in their mind. The situation around can be the case. Environment also determines the chance of success someone has when they are speaking. people around him, audience, capacity of speakers' voice, shyness, anxiety, and the fear of making mistake are common factors that usually affects students' speaking skill development.

Leong \& Ahmadi (2017) stated that inhibition is the first problem that the students encounter in class. When they want to say something in in classroom they are sometimes inhibited. They are worried about making mistakes and fearful of criticism. They are ashamed of the other students' attention towards themselves (Leong\&Ahmadi 2017)

Prior to any other problems, motivation is the core of successful skills. Without motivation, the other factors that affecting students' speaking skill development will still attached to a student's psychology. When they encounter a group of people where speaking activity is required in the current situation, a motivation powers them up to speak their minds. Mazouzi (2013) states that if motivation is to be successful, then, it must draw on the whole person and develops his/her self-esteem. Self-esteem is considered an important affective element in the process of scholastic and educational achievement. Henceforth, its absence results the mistrusting of learners own abilities which lead them to perform low as an outcome of this lack confidence. 


\section{RELATED STUDIES}

\section{This section presents several previous studies that relate to the present study.}

The first is the study conducted by Al-twairish (2009) in which he attempts to measure the effect of the implementation of the communicative approach (CA) on the listening and speaking skills of Saudi third year secondary students. In order to address this issue, a quantitative study was conducted on two randomly selected intact classes at Dammam Tenth Secondary School. These two classes were assigned as experimental group (37 students) and control group (41 students). It was particularly hypothesized that the students taught according to the CA would score higher in the post-test than in the pre-test and that there would be statistically significant differences at the level of .05 between the post-test mean scores of the experimental group and the control group. Various communicative activities were used with the experimental group while the control group was exposed to traditional, non-communicative, instruction using structurally based methods, such as the audio-lingual method. A pre-test was administered to both groups at the beginning of the experiment to ensure that they had the same language background. At the end of the experiment, a posttest was assigned to both groups to determine whether the CA had positively affected the students' listening and speaking abilities. The experiment lasted approximately seven weeks of the first semester.

The second is, The study conducted by Vongxay (2013) which entitled "The implementation of Communicative language teaching (CLT) in an English department in a Lao higher educational institution: a case study" explores the understandings and attitudes of English teachers in adopting a Communicative Language Teaching (CLT) approach into their classrooms. It investigates factors that promote or hinder EFL teachers' implementation of this teaching approach into Lao higher educational institutions English classrooms. It also examines the syllabi that influence them in teaching communicative English. This qualitative study investigated the perceptions of English teachers in a Department of English and a case study approach was applied in order to explore teachers' understandings of CLT. Ten English teachers from one department in a Lao higher education institution were interviewed using semi-structured interviews. The study compares the literature about communicative English teaching with the findings of data collected from these ten onetoone, in-depth interviews in the same setting. The findings indicated that the factors that affected the implementation of CLT in the Lao context related to teachers' factors include: misconceptions of CLT, traditional grammar-based teaching approach, teachers' English proficiency and lack of CLT training. The issues raised from students include: students' low English proficiency, students' learning styles and behaviours, and lack of motivation to develop communicative competence. Other difficulties caused by educational system were: 
the power of the examination, class size, and insufficient funding to support CLT and the last factors caused by CLT itself was: the lack of CLT interaction in society and school.

Third is the study conducted by Efrizal (2012) which entitled 'Improving students' speaking through Communicative Language Teaching method at ts Ja-alhaq, Sentot Ali Basa islamic boarding school of Bengkulu. The main purpose of this study is to know the improvement of teaching English speaking by using Communicative Language Teaching method. The method of this research is classroom action research (CAR). The data in this research is used percentages analysis. The respondents of this research are VII A students of Mts Ja-alhaq, Sentot Ali Basa Islamic Boarding School of Bengkulu which consist of 25 students. Based on result of data analysis there are improvements on students' speaking achievement in each cycle. The data shows that in pre-assessment students' speaking is $0 \%$ (excellent), $0 \%$ (very good), 20\% (good) 36\% (low) and 44\% (failed). In cycle I students speaking achievement is $0 \%$ (excellent), $8 \%$ (very good), 24\% (good), 32\% (low), 36\% (failed). In cycle II the students speaking achievement is $0 \%$ (excellent), 16\% (very good), $44 \%$ (good), $20 \%$ (low) and 20\% (failed). In cycle III students' speaking achievement is $12 \%$ (excellent), 20\% (very good), 56\% (good), 8\% (low) and 4\% (failed). In cycle IV students' speaking achievement is $24 \%$ (excellent), $48 \%$ (very good), $28 \%$ (good), $0 \%$ (low) and $0 \%$ (failed). This research indicates that the using of Communicative Language Teaching method can improve students' speaking achievement at the first year students of Mts Ja-alhaq, Sentot Ali Basa Islamic Boarding School of Bengkulu academic year 20011/ 2012.

Finally, the study conducted by Irmawati (2012) which entitled "Communicative Approach: An alternative Method Used in Iproving students' Academic Reading achiement. She attempts to measure the use of communicative approach for students' reading skill. Academic reading is a difficult subject to be mastered. It is needed because most of books or references are written in English. The emphasis is on academic reading which becomes a compulsory subject that must be taught and understood in Faculty of Letters UAD Yogyakarta. Communicative approach is used and applied as an alternative method in the process of teaching-learning that focuses on language as a medium of communication. Communication ability involves in understanding fully the vocabulary, grammar, comprehension, and all aspects of English skills such as reading, listening, speaking and writing. One main focus of the classroom action research that appears from communicative approach which is applied in the process of teaching-learning academic reading will be discussed. The objectives are (1) How is the application of communicative approach?, (2) How far is the influence of using communicative approach in teaching academic reading? It includes the study intensity of the students, the benefit and the weakness of using the approach. 


\section{RESEARCH METHODOLOGY}

\section{Research design}

This study was analyzed quantitatively. Researcher had chosen an experimental study.

Experimental study is a design in which occurs treatment and procedures. The outcome of research using this design is also observed. The researcher used Experimental study using two groups of pre-posttest design.

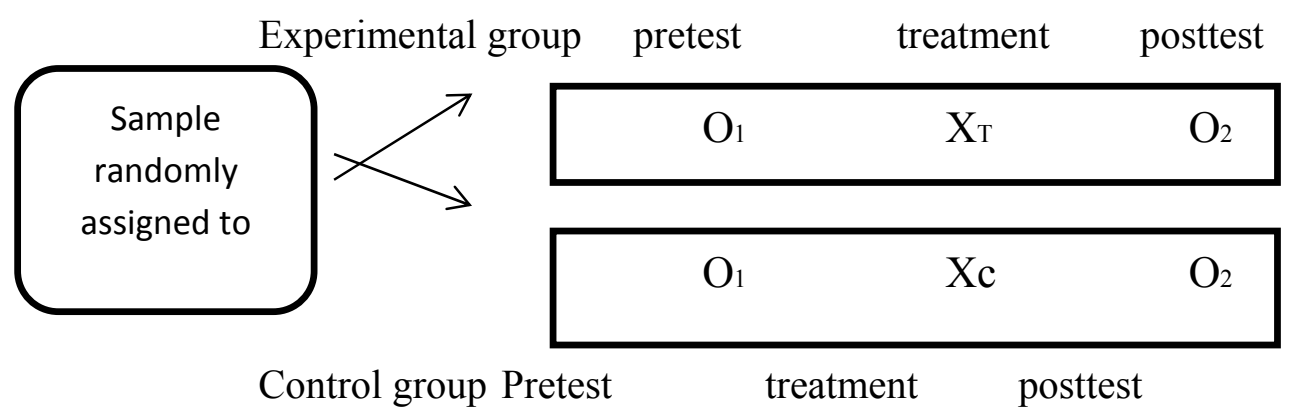

$\mathrm{O} 1$ and $\mathrm{O} 2$ represent the pre-test and post-test assessment

$\mathrm{XT}$ represents the treatment condition.

$\mathrm{XC}$ represents the control treatment condition.

(Adapted from Johnson \& Christensen, 2004, p. 283)

\section{Population of the study}

The population of this study were the third semester students of English Department in Manado State University.

\section{Sample of the study}

The sample of this study was one class which was speaking class and the class was chosen from literature class because in Manado State University there are 2 programs, those are English Education class and English Literature class. There are 2 classes in literature program and 8 classes in education program at English department. The researcher had explained the situation to the students of the speaking class and there were a class specified for this research. The class met twice a week, and the researcher had ran the research in two months so there were 16 meetings before the posttest. The class which became sample were randomly divided into two groups, first was the experimental group which was taught according to Communicative Language Teaching method and the control group which was taught according to traditional method. 


\section{Instrument}

As the researcher has stated before, this study were using quantitative research. Pre and posttest were assigned to students. The researcher had designed a test covering speaking skill

The data were collected based on the results of speaking skill test.

\section{Data Analysis}

The data collected were calculated using $t$-test with formula

$$
\begin{aligned}
t & =\frac{\overline{\mathrm{x}}_{1}-\overline{\mathrm{x}_{2}}}{\sqrt{\frac{S_{1}^{2}}{n_{1}}+\left(\frac{S_{2}^{2}}{n_{2}}\right)}} \\
\mathrm{S}^{2} & =\frac{\left(n_{1}-1\right) s_{1}^{2}+\left(n_{2}-1\right) S_{2}^{2}}{\left(n_{1}+n_{2}-2\right)}
\end{aligned}
$$

and to assess the speaking test, rubric below is used:

80-100 : Excellent

66-79 : Good

$56-65$ : enough

40-55: low

30-39 : Failed

(Arikunto 1987 as cited in Pansing,J 2012)

Based on the rubric above, the researcher made the criteria as written below:

Fluency: 30 points.

Accuracy: 30 points

Pronunciation: 15 points

Vocabulary: 15 points

Intonation: 10 points

\section{Hypotheses}

Along this study, there were two hypotheses framed. The two hypotheses were Null hypothesis (Ho) and the alternative hypothesis (Ha). The researcher described the two hypotheses as stated below:

Null Hypothesis (Ho) there was no difference between the two groups divided as sample of this research. If this hypothesis was true, the alternative hypothesis would have been rejected and the answer to the research question would have stated that there was no significant improvement in students who were taught according to CLT principles in their Oral English skill. 


\section{Alternative Hypothesis (Ha)}

This hypothesis stated the opposite of the Null Hypothesis. The researcher framed the hypothesis as "There is a significant effect and improvement on students who are taught based on Communicative Language Teaching method in their oral English skill." If this hypothesis was true, then the Null hypothesis was rejected.

\section{Findings}

The research design that is used in this study is true experimental with pre-test and post-test. The study was conducted in the third semester in English department of Manado State University.

Pretest was administered before the treatment to check students' Oral English skill. From the result of the pre-test, in control group the lowest score was 40 obtained by 1 student the highest was 60 obtained by 3 students, whereas their average score was 45-55. As in experimental group, 75 was the highest score obtained by a student and 55 was the lowest and their average score was 70 .

After the researcher did the treatment, posttest then administered and the result from the control group were 85 gained by a student and 55 was the lowest. The highest gain score obtained by 2 students was 25 and their average score was 55 .

As for the experimental group, there were some students achieved perfect score which was 100 and the lowest score was 70 , and their average score was 85 . The gain score they had were 25 and 30.

The scores obtained by the students were computed to see the difference between pre-test and post-test to gain the statistical numeric which then used to analyze the data, the writer computed the data to find the mean scores, standard deviation and the square standard deviation. After computing the data, the writer used $t$-test to see whether or not there is a significant difference between experimental and control group

Table 1. pretest scores obtained by students in control group

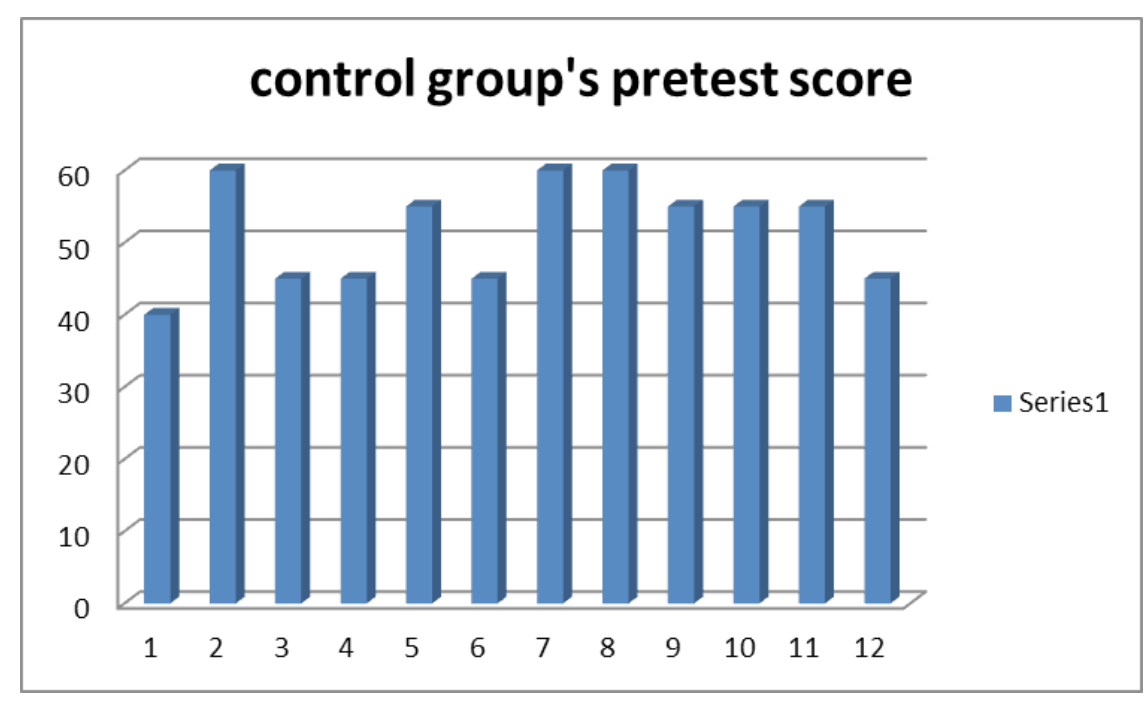


The table above shows the score from students' pretest which was administered before the treatment. It clearly shows the lowest score and the highest that the students have had achieved. The highest was 60 obtained by 3 students and the lowest score was 40 obtained by 1 student, whereas their average score was 45-55.

Table 2. posttest scores obtained by students in control group

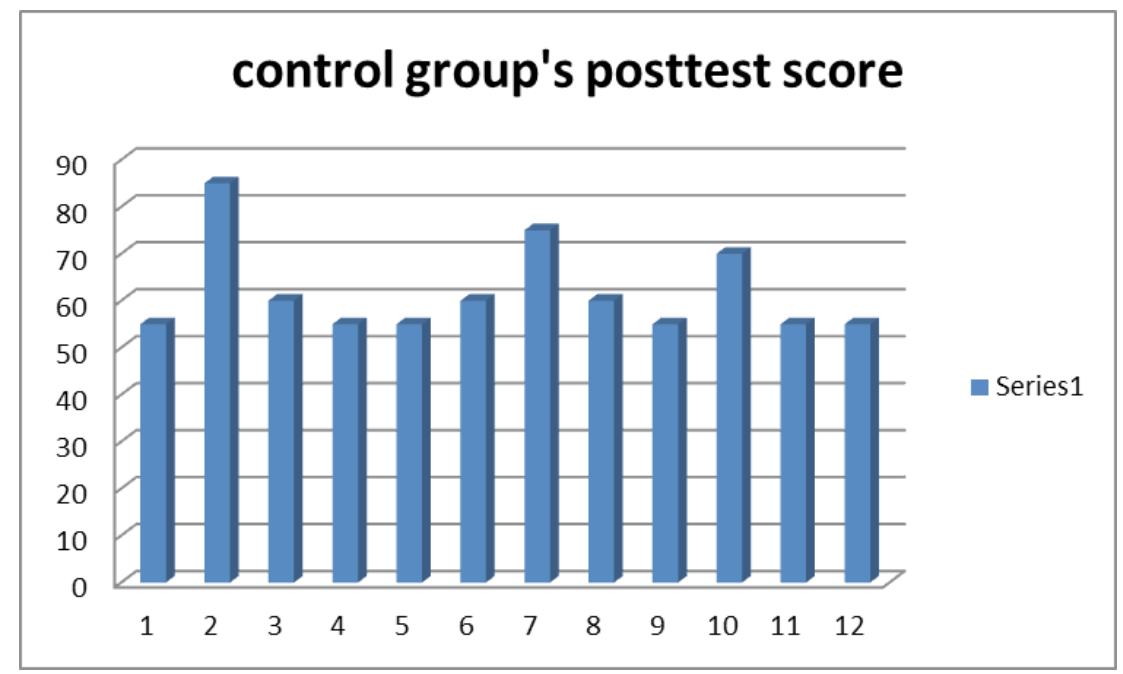

Table 2 above shows that the 55 was the lowest and the highest score was 85 gained by a student in control group and their average score was 55 .. However, there was still such a big leap in some students' achievement from the score that they had in pretest. The highest gain score obtained by 2 students was 25 .

Table 3. pretest scores obtained by students in experimental group before treatment

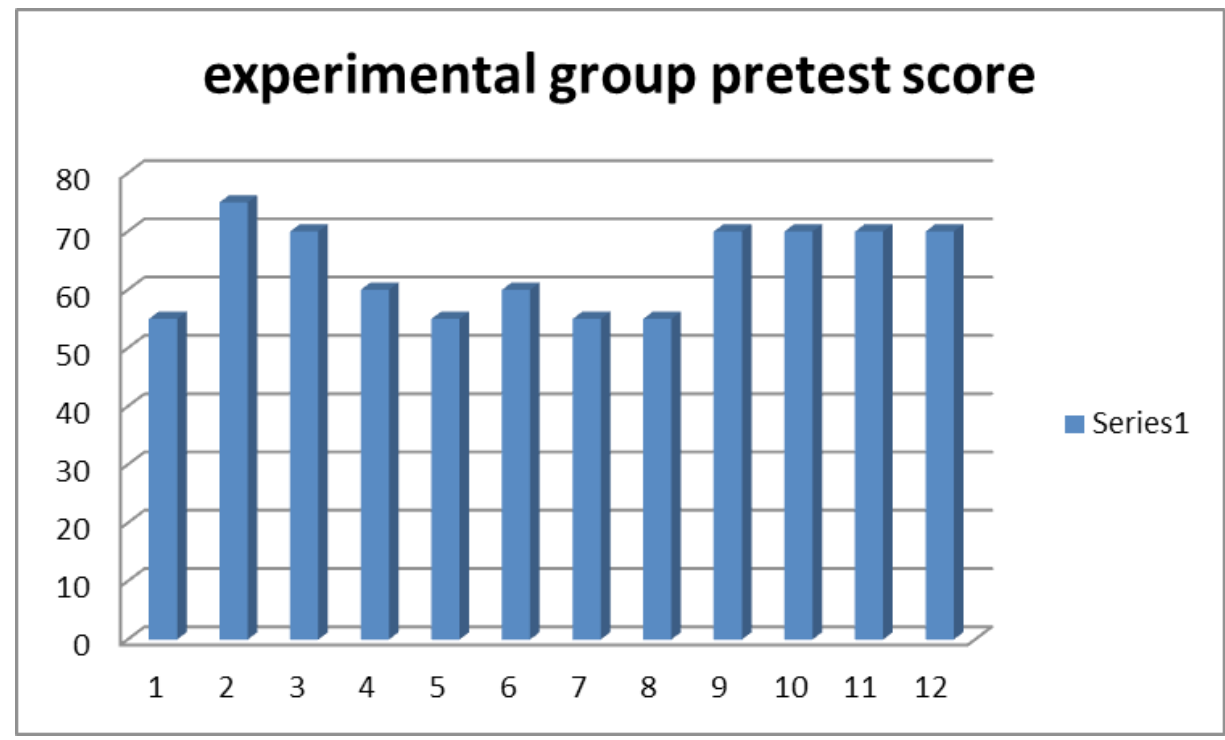


Experimental group was the one who were taught based on Communicative Language teaching principles. The table above shows the students' pretest score. 55 was the lowest and 75 was the highest score obtained by a student and their average score was 70 .

Table 4. posttest scores obtained by students in experimental group after treatment

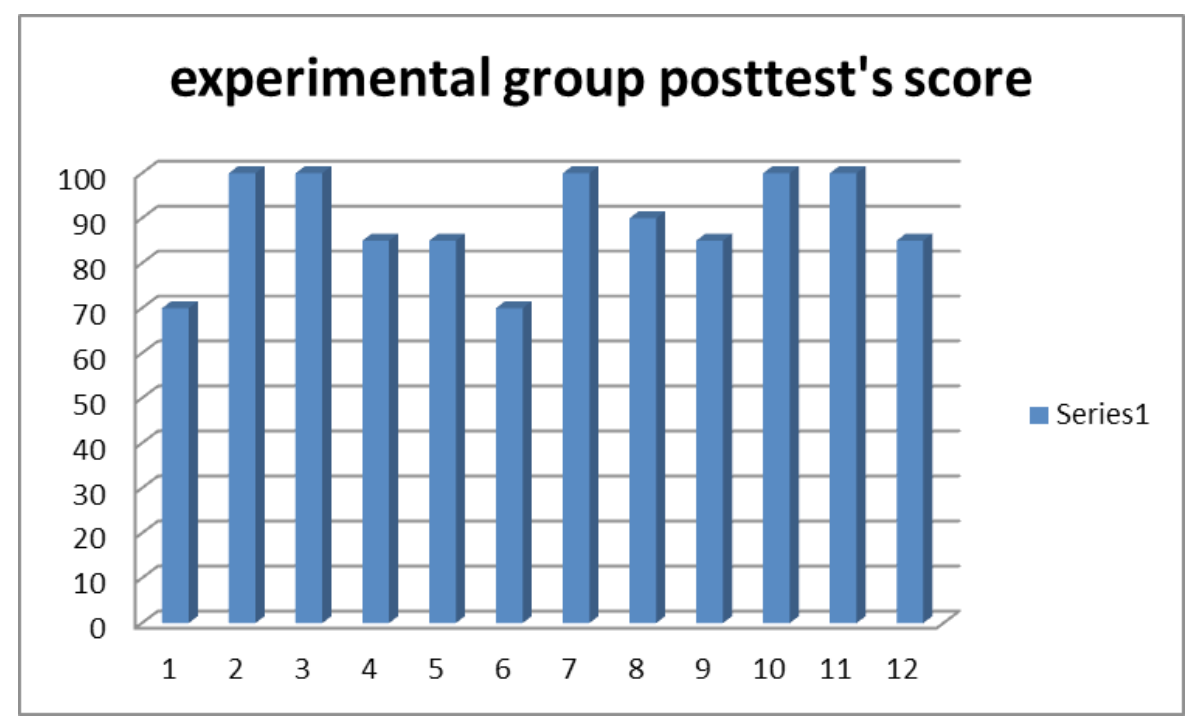

In experimental group, the lowest score was 70 obtained by 2 students. However there were 5 students achieved perfect score which was 100 and their average score was 85 . The gain score they had were 25 and 30 .

Table 5 below presents the data obtained from both groups and the gain score:

\begin{tabular}{|c|c|c|c|c|c|}
\hline \multicolumn{2}{|c}{ Control } & \multicolumn{2}{c|}{ experimental } & \multicolumn{2}{c|}{ gain score } \\
\hline Pretest & Posttest & pretest & posttest & control & experimental \\
\hline 40 & 55 & 55 & 70 & 15 & 15 \\
\hline 60 & 85 & 75 & 100 & 25 & 25 \\
\hline 45 & 60 & 70 & 100 & 15 & 30 \\
\hline 45 & 55 & 60 & 85 & 10 & 25 \\
\hline 55 & 55 & 55 & 85 & 0 & 20 \\
\hline 45 & 60 & 60 & 70 & 15 & 10 \\
\hline 60 & 75 & 55 & 100 & 15 & 45 \\
\hline 60 & 60 & 55 & 90 & 0 & 35 \\
\hline 55 & 55 & 70 & 85 & 0 & 10 \\
\hline 55 & 70 & 70 & 100 & 25 & 30 \\
\hline 55 & 55 & 70 & 100 & 15 & 30 \\
\hline 45 & 55 & 70 & 85 & 10 & 10 \\
\hline
\end{tabular}


The gain score obtained by the students were computed to see the difference between pre-test and post-test to gain the statistical numeric which then used to analyze the data, the writer computed the data to find the mean scores, standard deviation and the square standard deviation as follows:

Table 6 mean scores and standard deviation and the square standard deviation

\begin{tabular}{|l|l|}
\hline Experimental group $\left(\mathbf{X}_{1}\right)$ & Control group $\left(\mathbf{X}_{2}\right)$ \\
\hline $\mathrm{N}=12$ & $\mathrm{~N}=12$ \\
$\bar{X}_{1}=23.75$ & $\bar{X}_{2}=12.08$ \\
$\mathrm{Sdx}_{1}=11.10$ & $\mathrm{Sdx}_{2}=8.65$ \\
$\mathrm{Sdx}_{1}{ }^{2}=123.21$ & $\mathrm{Sdx}_{2}{ }^{2}=74.82$ \\
\hline
\end{tabular}

After computing the data, the writer used $t$-test to see whether or not there is a significant difference between experimental and control group.

$t$-test with significant level $a=0,05$

$t$-test calculated with formula:

$$
\begin{aligned}
& t=\frac{\overline{\mathrm{x}}_{1}-\overline{\mathrm{x}_{2}}}{\sqrt{\frac{S_{1}^{2}}{n_{1}}+\left(\frac{S_{2}^{2}}{n_{2}}\right)}} \\
& \mathrm{S}^{2}=\frac{\left(n_{1}-1\right) S_{1}^{2}+\left(n_{2}-1\right) S_{2}^{2}}{\left(n_{1}+n_{2}-2\right)} \quad \text { Sugiyono, } 2009
\end{aligned}
$$

Explanation:

$\bar{x}_{1} \quad=$ mean score of experimental group

$\bar{x}_{2} \quad=$ mean score of control group

$S_{1}^{2} \quad=$ standard deviation (experimental group)

$S_{2}^{2} \quad=$ standard deviation (control group)

$n_{1} \quad=$ numbers of sample (experimental group)

$n_{2} \quad=$ numbers of sample (control group)

$S \quad=$ standard deviation

With the hypothesis to be tested:

Ha (Alternative hypothesis) : the mean score of experimental. If $t$-test value is bigger than $t$-tabulated then Ho is rejected.

Ho (Null hypothesis): the mean score of control group. If $t$-test value is smaller than $t$-tabulated then Ha is rejected. 
Statistical analysis

$$
\begin{aligned}
& \text { Dik: } \bar{X}_{1} \bar{X}_{1}=23.75 \quad \bar{X}_{2} \bar{X}_{2}=12.08 \\
& \mathrm{Sdx}_{1}=11.10 \quad \mathrm{Sdx}_{2}=8.65 \\
& S_{1}^{2}=123.21 \quad S_{2}^{2}=74.82 \\
& \mathrm{~S}^{2}=\frac{\left(n_{1}-1\right) S_{1}^{2}+\left(n_{2}-1\right) S_{2}^{2}}{n_{1}+n_{2}-2} \\
& =\frac{(12-1) 123.21+(12-1) 74.82}{12+12-2} \\
& =\frac{(11) 123.21+(11) 74.82}{22} \\
& =\frac{1355.31+823.02}{22} \\
& =\frac{2178.33}{22} \\
& \mathrm{~S}^{2}=99.015 \\
& \mathrm{~S}=\sqrt{99.015} \\
& =9.951 \\
& t \text {-test }=\frac{\bar{x}_{1}-\bar{x}_{2}}{\sqrt[s]{\frac{1}{n_{1}}+\frac{1}{n_{2}}}} \\
& =\frac{23.75-12.08}{9.951 \sqrt{\frac{1}{12}+\frac{1}{12}}} \\
& =\frac{11.67}{9.95 \sqrt[1]{0,08+0,08}} \\
& =\frac{11.67}{9.951 \sqrt[1]{0,16}} \\
& =\frac{11.67}{9.951(0,4)} \\
& =\frac{11.67}{3.98} \\
& =2.932
\end{aligned}
$$

From the calculation, we can see that $t$-test value is 2.932 based on the distribution of $t$-table $\propto \propto 0,05$ with degrees of freedom $\mathrm{n}_{1}+\mathrm{n}_{2}-2=12+12-2=22$ and tabulated $t$-test value 2.074 . 
From the explanation, it is clearly seen that $t$-test value is bigger than tabulated $t$-test value. $t$-test value $=2.932>t$-tabulated $=2.074$. The result also clarified that Ho is rejected and $\mathrm{Ha}$ is accepted. It concludes that there is a positive effect in students Speaking skill improvement through the use of Communicative Language Teaching method.

\section{Discussion}

The numbers of participant were 24 students of advance speaking class in English department. Before the treatment given, pre-test with the same kind of test were administered to all 24 students to see how good they are in speaking. Highest score was obtained by one student which was 75 and the lowest were obtained by one student which was 40 . Clearly it shows us that even from the pretest there was at least 1 student with better comprehension than the rest. It is said better because there was standard grade determined in scoring the speaking assessment and the standard was 30 . As for the rest, 4 students obtained 45,8 students obtained 55, 5 students obtained 60 and 5 students obtained 70. After observing the pretest score that the students have had gained, the researcher then concluded that their speaking skill were low. As a matter of fact, it was lower than expected out of third semester students who had gone through 2 classes of speaking before in the first and second semester.

There were two groups divided for the sake of this research. The first one was experimental group who were taught according communicative language teaching principles. The second was control group who weren't taught according to CLT principles. Before giving the treatment to experimental group, the researcher first explained the course and the method to be applied which was according to CLT principles. The treatment given was in form of group dialogues, dialogues in pairs and describing a person or a place. At some meetings during the treatment, the experimental group was given the chance to express their thoughts and made a dialogue which was done in group with whatever topic they wanted.

After 12 weeks of experiment, posttest was administered to both groups to see their comprehension. Especially for experimental group, the posttest was administered to find out whether or not there is an improvement after weeks of treatment. As it is shown earlier in this chapter, the mean scores between control group and experimental group are significantly different. The total mean score obtained by control group is 12.08 and the total mean score obtained by experimental group is 23.75. In experimental group, 5 people achieved perfect score which is 100 . 1 student gained 90, 4 students obtained 85,2 students obtained 70 .

Compared to the control group, experimental group achieved more gain score. The highest gain score in control group was 25 points and the highest in experimental group was 45. Although the numbers gained by a student was not enough to be said excellent, still, 25 is such a leap from 60 to 85 . There was, however in control group, some students made no 
progress at all. Some students obtained the same score as they gained when the pretest was administered. We can see in the table 5, 3 students have had made no achievement at all because their score stayed in 55 and 60 .

The lack of opportunity to let them stimulate their speaking skill and brainstorming might be the cause. They weren't given as much chances to explore their speaking ability as the students in experimental group did. Moreover, there was no such treatment given to enhance their skill. But this doesn't mean the other approaches that were used in teaching speaking cannot help students in their speaking skill mastery. The highest score which was obtained by a student in control group (85) proves that somehow the approach succeeds.

\section{Conclusion}

From the discussion, it can be concluded that the use of Communicative Language Teaching method is effective in improving students' Speaking skill.

The big difference between experimental and control group could be attributed to some reason.

Firstly, during the weeks of experiment the experimental group had the opportunities to practice a real-life situation in learning English. The control group did not have those opportunities. Secondly the experimental group was given the chance to also have interaction with English native speaker to really experience a real-life situation where these students have no choice but to speak English and the control group didn't because they were only given drills by the researcher.

Communicative language teaching provides the opportunity to practice a variety activities, encouraging students to speak freely based on their own experience and their best knowledge of English Speaking skill, supports students' confidence, and fitting students' needs and interest. Communicative language teaching method is an appropriate way with profits to help students expanding their English speaking skill. It will give contribution to English Foreign learners.

\section{REFERENCES}

Al-Twairish Nasser (2009). The effect of the communicative on the listening and speaking skills of Saudi secondary school students: an experimental study. King Saud University Deanship of higher studies department of English language and literature.

Arikunto, Suharsimi. (1987). Prosedur Penelitian Suatu Pendekatan Praktik. Jakarta

Bina Aksara. Bahri, Saiful Djamarah dan Aswar Zain

Baele, J (2002). Is communication language teaching a thing of the past?. In Khan, A.I. (2013) Speaking skills and teaching strategies: the case of an EFL classroom. 
King Abdulaiz University Community college, Jeddah-Saudi Arabia.

Boonkit, K. (2010). Enhancing the development of speaking skills for non-native speakers of English. Faculty of Arts, Silpakorn University, Nakhon Pathom, 73000

Brown, H.D. (1994). Teaching by principles: an interactive approach to language pedagogy. In Coskun, A. (2011). Investigation of the Application of Communicative Language Teaching in the English Language classroom: A case study on teachers' attitudes in Turkey. Journal of Linguistics amd language teaching. Vol. 2

Dendrinos, B. (P. 4, P.5). ELT Methods and Practices, Unit 7. Developing Speaking skills. School of Pholosophy, Faculty of English Language and Literature. University of Athens. PDF

DEPDIKNAS (2003). PELAYANAN PROFESIONAL KURIKULUM 2004: KURIKULUM BERBASIS KOMPETENSI. In Munawar (2015), Improving speaking skills through the learning community techniques, Syiah Kuala University, Banda Aceh. English Education Journal.

Efrizal, D. (2012). Improving students' speaking through Communicative Language TeachingMethod at Mts Ja-alhaq. Sentot Ali basa Islamic boarding school of Bengkulu, Indonesia. State Institute of Islamic studies.

Gordin, Michael D. (2015). Scientific Babel: How science was done before and after global English. Chicago, Illinois: University of Chicago Press.

Irmawati, N.D. (2012). Communicative approach: An alternative method used in improving students' academic reading achievement.

Johnson, B., \& Christensen, L. (2004).Educational research: Quantitative, qualitative, and mixed approaches. USA, Boston:Pearson Education, Inc.

Larsen-Freeman, D. (2000). Techniques and Principles in Language teaching ( $2^{\text {nd }}$ ed.) Oxford: Oxford University Press.

Mazouzi, S. (2013). Analysis of some factors affecting learners'oral performace. Faculty of Letters and Languages, University of BISKRA.

Paulista, S. \& Gomez. (2014). The application of communicative language teaching: a particular case in a Polish primary school. Faculty of Education, Translation and Human Sciences- University of Vic.

Richards, J. (2006). Communicative Language Teaching Today. Cambridge University Press.

(2008), Teaching listening and speaking. From theory to practice. Cambridge University Press

Sugiyono (2009.) : Metodologi Penelitian Pendidikan, Pendekatan Kuantitatif, Kualitatif, dan $R \& D$, Alfabeta, Bandung:

Tuan, N.H \& Mai, T.N (2015). Factors affecting students' speaking performance at LE 
Thanh Hien high school. In Leong \& Ahmadi (2017). An analysis of factors influencing learners'English speaking skill. International Journal of Research in English Education

Villagran, M.D.M.S. (2008). 4 Skills: Speaking. PDF

Vongxay, H. (2013). The implementation of communicative language teaching (CLT) in an English department in a Lao higher education institution: a case study. Unitec Institution of Technology, New Zealand.

Ying, L.A (2010). Communicative activities in ELT classrooms in China. University of Wisconsin-Platteville. 